\title{
Possible Impact of 190G > A CCR2 and $\triangle 32$ CCR5 Mutations on Decrease of the HBV Vaccine Immunogenicity-A Preliminary Report
}

\author{
Maria Ganczak $^{1, *}$, Karolina Skonieczna-Żydecka ${ }^{2}$, Marzena Drozd-Dąbrowska ${ }^{1}$ and \\ Grażyna Adler ${ }^{2}$ \\ 1 Department of Epidemiology and Management, Pomeranian Medical University, Szczecin 70-204, Poland; \\ marzena.drozd@pum.edu.pl \\ 2 Department of Gerontobiology, Pomeranian Medical University, Szczecin 70-204, Poland; \\ karolina.skonieczna-zydecka@pum.edu.pl (K.S.-Ż.); grazyna.adler@pum.edu.pl (G.A.) \\ * Correspondence: mganczak@pum.edu.pl; Tel.: +48-91-480-0965 \\ Academic Editor: William Chi-shing Cho \\ Received: 14 November 2016; Accepted: 5 February 2017; Published: 8 February 2017
}

\begin{abstract}
Background: Chemokine genetic variations are involved in infectious diseases such as hepatitis B virus (HBV). Several allelic variants might, in theory, affect the outcome of vaccination. Objectives: This study was carried out to examine the associations of $\triangle 32$ CCR5 and 190G > A CCR2 polymorphisms with a response to a primary course of three HBV vaccinations. Methods: Between December 2014 and December 2016, patients from three randomly selected primary care clinics in the West Pomeranian region (Poland), 1 month after receiving the third dose of HBV vaccine, were enrolled. Enzyme-linked immunosorbent assay (ELISA) system version 3.0 was used to detect anti-HBs and anti-HBc totals. The identification of polymorphisms were performed by a polymerase chain reaction technique using a single primer extension assay. Genotype distributions of responders versus non-responders to HBV vaccination were compared on the basis of anti-HBs level. Results: In 149 patients (mean age 60 years) the mean anti-HBs level was $652.2 \pm 425.9 \mathrm{mIU} / \mathrm{mL}$ (range: $0-1111.0 \mathrm{mIU} / \mathrm{mL})$. There were $14.1 \%(n=21)$ non-responders to the $\mathrm{HBV}$ vaccine (anti-HBs $<10.0 \mathrm{mIU} / \mathrm{mL}$ ). The wild type/ $\triangle 32$ genotype of CCR5 gene was found in $18.1 \%$ participants, and $1.3 \%$ were $\Delta 32 / \Delta 32$ homozygotes. The frequency of allele $\mathrm{A}$ of the CCR2 gene was $11.1 \%$. Lower anti-HBs levels in $\Delta 32 / \Delta 32$ homozygotes were observed $(\mathrm{Me}=61 \mathrm{mIU} / \mathrm{mL}$ vs. Me $=660.2 \mathrm{mIU} / \mathrm{mL} ; p=0.048)$. As age was found to be a correlate to the anti-HBs titer $(r=-0.218$, $p=0.0075 ; 95 \%$ CI: $-0.366--0.059)$-an analysis of a co-variance was performed which found a statistically significant $(p=0.04)$ difference in anti-HBs titres between $\Delta 32 / \Delta 32$ homozygotes and other CCR5 genotypes. The association between anti-HBs titres and CCR2 genotypes was not statistically significant. Conclusions: Our study-which is a preliminary report that suggest this topic deserves further observation with larger sample sizes, different ethnicities, and other single nucleotide poly-morphisms (SNPs)—suggests the possible involvement of CCR5 polymorphism in impairing the immunologic response to $\mathrm{HBV}$ vaccination, predominantly in relation to the passage of time.
\end{abstract}

Keywords: HBV; vaccination; immunogenicity; CCR5; CCR2; polymorphism

\section{Background}

In humans, hepatitis B virus (HBV) is the most prevalent and the main infectious agent leading to liver disease. Viral hepatitis B (HB) continues to be a cause of considerable morbidity and mortality. The World Health Organization estimated that in 2012 around 240 million people were chronically 
infected with HBV worldwide, and approximately 780,000 die per year as a consequence of acute disease and chronic complications, such as cirrhosis and hepatocellular carcinoma. Globally, two billion people, more than a third of the world's population, have been infected with HBV [1]. The prevalence of HBV in the Polish population has been found to be around $0.5 \%-1.5 \%$ [2].

Since 1981 HB has become a vaccine-preventable disease, due to safe and effective vaccines, typically given in a three-dose series [3]. In healthy individuals post-vaccine sero-conversion is as high as $90 \%-100 \%$ [4]. A concentration of anti-HBs $1-2$ months after a primary series $\geq 10 \mathrm{mIU} / \mathrm{mL}$ is generally accepted as offering protection. Determinants that may decrease the immunogenicity include vaccine, host, and genetic factors [3-5].

Among genetic factors involved in host immune response to viral infection, chemokines and their receptors play a critical role; the most frequently studied being CCR2 and CCR5, and their polymorphisms: $\Delta 32$ and $190 \mathrm{G}>\mathrm{A}$, respectively.

CCR5 is a CC chemokine receptor, which influences the migration of granulocytes, macrophages, immature dendritic cells, CD8+ lymphocytes, Th1 lymphocytes and their activation. It is also a co-receptor for HIV entry into host cells [6,7]. The CCR5 gene consists of a single coding exon, with non-functional allele containing a $32 \mathrm{bp}$ deletion. A heterozygous $(\mathrm{wt} / \Delta 32)$ presents reduced levels of CCR5 on the cell surface compared to a wild homozygous CCR5 $(\mathrm{wt} / \mathrm{wt})$, while a homozygous mutant $(\Delta 32 / \Delta 32)$ presents higher levels of CCR5 [6]. C-C chemokine receptor 2 , is involved in modulating the immune response, as well as recruiting monocytes/macrophages to the sites of inflammation [8].

The polymorphism of the CCR5 gene and DNA alterations might affect gene expression and then protein function, while the polymorphism G-A transition at position 190 in CCR2 gene, introducing a conservative change into the first transmembrane domain, is not associated with any clinical abnormality [9].

The frequency of allele $\Delta 32$ of CCR5 gene varies from about $5 \%$ to $13 \%$ in different populations, and of allele A of CCR 2 gene from about $10 \%$ to $25 \%$ [10,11].

Chemokine genetic variations have been involved in infectious diseases such as HIV, HCV (Hepatitis C), HPV (Human papillomavirus), West Nile Virus, as well as HBV [12-15]. Previous studies suggested that the polymorphism 190G > A of the CCR2 gene is associated with enhanced protection against HPV-16 infection [16]. Independent studies demonstrated the protective effect of CCR5 $\triangle 32$ in recovery from a HBV infection, and provided genetic epidemiological evidence for the role of CCR5 in the immune response to HBV [14,15]. However, the role of chemokines in HBV prevention has not been fully clarified [17]. Several allelic variants might, in theory, affect the outcome of vaccination. Nevertheless, data on the relationship of both $\triangle 32$ CCR5 and 190G > A CCR2 polymorphisms and the HBV vaccine immunogenicity are sparse.

\section{Objectives}

The study objective was to examine $\triangle 32$ CCR5 and 190G > A CCR2 polymorphisms in the context of $\mathrm{HBV}$ vaccination response.

\section{Methods}

\subsection{Setting and Sampling}

The study was conducted between December 2014 and December 2016 among 185 consecutive, unrelated adult patients presenting one month after taking a third HBV vaccination dose, at three randomly selected urban primary care clinics (PCCs) located in Szczecin, in the West Pomeranian region of Poland. Patients with serological markers of HBV infection (anti-HBc total) were excluded from the study $(n=24 ; 12.5 \%)$. Among those remaining $(n=161)$, the extraction of genome DNA failed in $12(7.5 \%)$, therefore 149 individuals were finally analysed. 


\subsection{Study Instrument}

After signing informed consent forms, participants filled out a questionnaire which anonymously queried them on their demographics (age, gender, weight and height), smoking habit and medical history of HB.

\subsection{Sero-Testing and Genetic Testing}

Blood samples were collected by venipuncture. Enzyme immunosorbent assay (ELISA) system version 3.0 (Abbott Laboratories Inc., Abbott Park, IL, USA) was used to detect anti-HBs and anti-HBc total.

Genomic DNA from leukocytes of peripheral blood, collected into sterile tubes containing ethylene diamine tetraacetic acid (EDTA) solution was isolated with the use the QIAamp DNA extraction kit (Qiagen, Hilden, Germany). The extraction followed manufacturer instructions; DNA samples were stored at $4{ }^{\circ} \mathrm{C}$. Subsequently, genotypes were determined by a polymerase chain reaction (PCR) technique, according to a previously described protocol with the following temperature profile: the initial denaturation for $C C R 2$ was $94^{\circ} \mathrm{C}$ for $5 \mathrm{~min} ; 38$ cycles of $20 \mathrm{~s}$ at $94{ }^{\circ} \mathrm{C}, 40 \mathrm{~s}$ at $57^{\circ} \mathrm{C}$ and $40 \mathrm{~s}$ at $72{ }^{\circ} \mathrm{C}$; for $C C R 5$ the initial denaturation was $94{ }^{\circ} \mathrm{C}$ for $5 \mathrm{~min}$; 38 cycles of $30 \mathrm{~s}$ at $94{ }^{\circ} \mathrm{C}, 30 \mathrm{~s}$ at $60^{\circ} \mathrm{C}$ and $45 \mathrm{~s}$ at $72{ }^{\circ} \mathrm{C}$; the final extension step was $72{ }^{\circ} \mathrm{C}$ for $7 \mathrm{~min}$ for each of the polymorphisms $[18,19]$. For the analysis of $C C R 2$ and $\triangle 32 C C R 5$ mutations, a sequence specific PCR was run using the following two primer pairs: forward $5^{\prime}$-TTG TGG GCA ACA TGA TGG-3' and reverse $5^{\prime}$-GCA TTC CCA AAG ACC CAC TC- $3^{\prime}$ and forward $5^{\prime}$-GAT AGG TAC CTG GCT GTC CAT- $3^{\prime}$ and reverse $5^{\prime}$-ACC AGC CCC AAG ATG ACT ATC T-3', respectively (TIB MOL BIOL, Poznan, Poland). After of the use of a BsaBI restriction enzyme (Thermo Fisher Scientific, Waltham, MA, USA), a wild allele (G) CCR2 gene was detected as a $163 \mathrm{bp}$ fragment, while a mutant allele (A) 145 and $18 \mathrm{bp}$, and wild (wt) and mutant $(\triangle 32)$ alleles of $C C R 5$ gene were detected as 242 and 210 bp fragments, respectively. For quality control purposes, results were verified by performing re-genotyping of randomly selected samples; all results were reliable and replicable. To assess possible differences in the frequencies of $\Delta 32$ and 190G $>\mathrm{A}$ polymorphisms, a control group from the HAPMAP database was used [20]. The study was approved by the institutional ethics committee (KB-0012/180/13).

\subsection{Statistical Analyses}

Mann-Whitney/t-student tests were used for the comparisons of continuous variables, a $\chi^{2}$ test to verify whether genotype and allele frequencies matched the Hardy-Weinberg equilibrium and to assess whether there are differences in genotype and alleles distribution between vaccine responders/non-responders. Genotype comparisons by means of anti-HBs values were performed using an ANOVA test, and nonparametric counterparts (Kruskall-Wallis, Mann-Whitney), as appropriate. The level of anti-HBs is influenced by gender, smoking and BMI (Body Mass Index) [3,5], so analyses of variance were initially performed separately for each and then together to determine any interactions between variables. To establish the OR and 95\% CI logistic regression was used. The significance level of the test was set to 0.05 . Statistical analyses were performed using the StatView version 5.0 software (BrainPower Inc., Calabasas, CA, USA).

\section{Results}

Patient demographic characteristics are shown in Table 1. 
Table 1. Study group characteristics * $(n=149)$.

\begin{tabular}{ccccc}
\hline Variable & All $(n=\mathbf{1 4 9})$ & Women $(n=85)$ & Men $(n=64)$ & $p^{* *}$ \\
\hline Age (years) & $59.4 \pm 13.6$ & $61.0 \pm 13.8$ & $57.2 \pm 13.0$ & 0.08 \\
Body mass $(\mathrm{kg})$ & 76.7 & 68.0 & 84.5 & $<0.0001$ \\
Height $(\mathrm{cm})$ & $167.4 \pm 8.5$ & $162.5 \pm 6.4$ & $173.9 \pm 6.3$ & $<0.0001$ \\
BMI $\left(\mathrm{kg} / \mathrm{m}^{2}\right)$ & 26.7 & 26.1 & 27.9 & 0.06 \\
\hline
\end{tabular}

* ex re variables that followed normal distribution data are shown as mean \pm standard deviation; for variables without normal distribution characteristics are expressed as median. ** women vs. men. BMI: Body Mass Index.

\subsection{Genotyping}

The following CCR5 $\triangle 32$ genotype frequencies were assessed: wild type/wild type (wt/wt): $80.6 \%(n=120), \mathrm{wt} / \Delta 32: 18.1 \%(n=27), \Delta 32 / \Delta 32: 1.3 \%(n=2)$.

Regarding CCR2 polymorphism the following genotype frequencies were identified: GG: 117 (78.5\%), GA: $31(20.8 \%)$, AA: $1(0.8 \%)$. The major allele frequency was $88.9 \%$.

The distribution of the $\triangle 32 C C R 5$ and gene CCR2 polymorphisms followed the Hardy-Weinberg equilibrium $\left(\chi^{2}=0.1605 ; p=0.73\right.$ and $\chi^{2}=0.4714 ; p=0.49$, respectively).

There were no differences in the frequencies of studied polymorphisms between the study group and HAPMAP controls (CCR5: $p=0.34$, CCR2: $p=0.81$ respectively).

\subsection{Anti-HBs Titres}

The median anti-HBs titre for the study participants was $652 \pm 4259 \mathrm{mIU} / \mathrm{mL}$ (range: $0-1111.0 \mathrm{mIU} / \mathrm{mL}$ ). There were $21(14.1 \%$ ) non-responders to the $\mathrm{HBV}$ vaccine (anti-HBs $<10.0 \mathrm{mIU} / \mathrm{mL}$ ) for whom the median anti-HBs titre was $0.0 \mathrm{mIU} / \mathrm{mL}$. For $128(85.9 \%)$ responders (anti-HBs $\geq 10.0 \mathrm{mIU} / \mathrm{mL}$ ) the median anti-HBs titre was $1001.0 \mathrm{mIU} / \mathrm{mL}$. There was a statistically significant difference in anti-HBs titres between the two groups $(p<0.0001)$. In women the median anti-HBs titre was $1001 \mathrm{mIU} / \mathrm{mL}$, in men $772.0 \mathrm{mIU} / \mathrm{mL}(p=0.08)$. Anti-HBs titres were negatively correlated with patient age $(r=-0.218, p=0.0075 ; 95 \% \mathrm{CI}$ : $-0.366--0.059)$; Figure 1 . No correlation was found regarding BMI values and anti-HBs titre ( $r=-0.019 ; p=0.82,95 \% \mathrm{CI}:-0.179-0.142)$, or associations regarding smoking status, gender and anti-HBs level ( $p=0.12 ; p=0.06$, respectively).

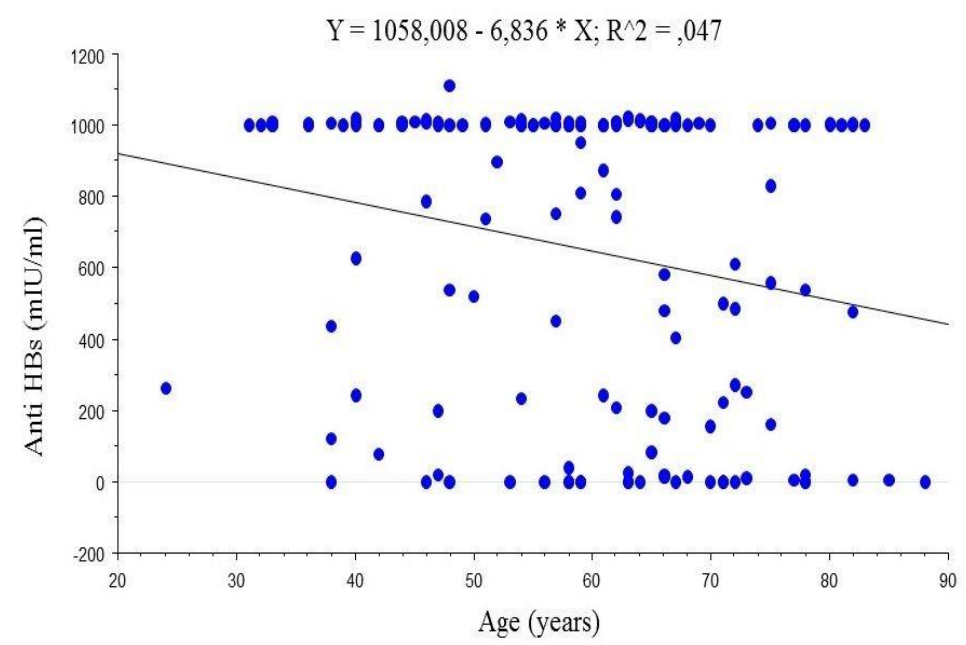

Figure 1. Correlation of anti-HBs titres after receiving the third dose of hepatitis B virus (HBV) vaccine with patient age $(n=149)$. 


\subsection{Associations between CCR2 and CCR5 Genotypes and Anti-HBs Titres}

In 21 non-responders medians of anti-HBs titres were $0.0 \mathrm{mIU} / \mathrm{mL}$ despite the CCR5 genotype; $p=0.95$. In 128 responders medians of anti-HBs titres were $1001.0 \mathrm{mIU} / \mathrm{mL}$ for individuals presenting $\mathrm{wt} / \mathrm{wt}$ and $\Delta 32 / \mathrm{wt}$ genotypes, and $122.0 \mathrm{mIU} / \mathrm{mL}$ for those presenting $\Delta 32 / \Delta 32$ genotype; $p=0.273$. The median of anti-HBs titres in CCR2 GG homozygotes was $1001 \mathrm{mIU} / \mathrm{mL}$, in GA heterozygotes $1001 \mathrm{mIU} / \mathrm{mL}$ and in the single AA homozygote $1001 \mathrm{mIU} / \mathrm{mL}$.

A one-way ANOVA revealed a statistically significant association between CCR5 genotype in a co-dominant model of inheritance and anti-HBs titres $(p=0.04)$. Therefore, we adapted a recessive model of inheritance for a $\triangle 32 C C R 5$ polymorphism. The median anti-HBs titre in $\Delta 32 / \Delta 32$ homozygotes was $61 \mathrm{mIU} / \mathrm{mL}$ and in other genotypes: $660.2 \mathrm{mIU} / \mathrm{mL}(p=0.0478)$.

Due to the lack of normal distribution in anti-HBs titre values, non-parametric tests were also performed. The analysis did not show statistical significance regarding the association between anti-HBs titres and the co-dominant model of $\triangle 32$ CCR5 model of inheritance $(p=0.16)$. However, a statistical tendency towards lower anti-HBs titres in $\Delta 32 / \Delta 32$ homozygotes was confirmed in a recessive model $(p=0.078)$.

Age, gender, BMI and smoking status were taken into consideration for further analyses when appropriate. As age was found to be a correlate to the anti-HBs titre the corresponding analysis of a co-variance was performed. A difference in anti-HBs titres between $\Delta 32 / \Delta 32$ homozygotes and other CCR5 genotypes was found to be statistically significant $(p=0.04)$; Figure 2 .

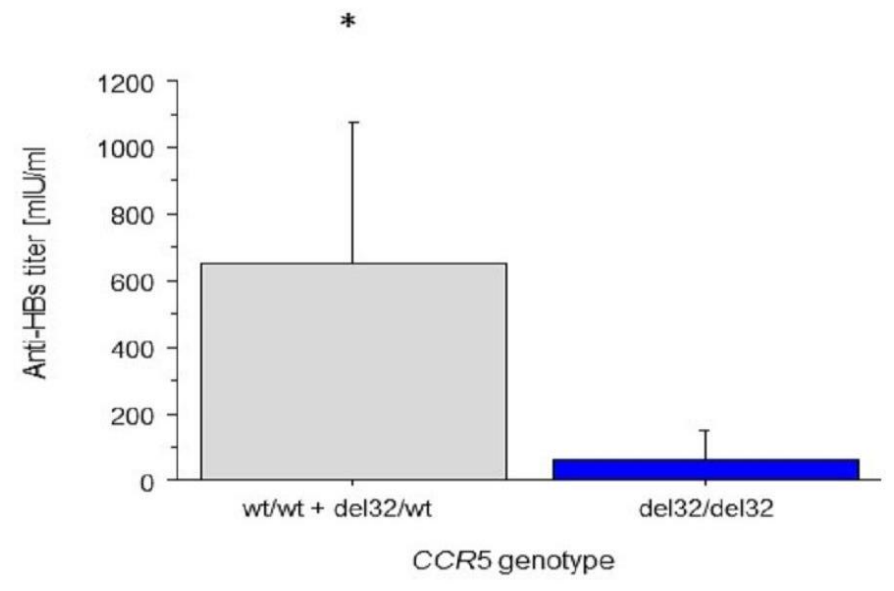

Figure 2. Anti-HBs titres by CCR5 recessive genotype and age as a cofactor ${ }^{*} p=0.04$; bars indicate standard deviations); $n=149$.

Additionally, two-way ANOVA for CCR5 recessive genotype and smoking as independent variables was performed; no significant results for the main effects of the analysis (CCR5: $p=0.07$; smoking: $p=0.97)$ and interactions (CCR5 * smoking: $p=0.66)$ were found. The OR of the $\triangle 32 C C R 5$ gene polymorphism in recessive manner towards real anti-HBs titres/vaccine response was found to not be statistically significant ( $p=0.265, p=0.197$, respectively).

No association between CCR2 genotype and anti-HBs titres were found in one-way ANOVA analyses in co-dominant, dominant, recessive and over-dominant models of inheritance $(p>0.05$, $p=0.33, p=0.41, p=0.42$, respectively). Nonparametric analyses in CCR2 genotype towards ant-HBS tires was confirmed to be nonsignificant in all models of inheritance $(p=0.45, p=0.21, p=0.69$, $p=0.24$, respectively).

Finally, post hoc power analyses using $G$ * Power [21] computer software was performed. This is a flexible statistical power analysis program for social, behavioural, and biomedical sciences. Statistical powers analyses observed were under the recommended 0.8 level [22], thus to obtain larger effects, the sample size would have to be increased. 


\section{Discussion}

\subsection{Results Overview}

Of the 149 patients, presenting at PCCs one month after receiving the third dose of HBV vaccine, $12.5 \%$ were not protected against $\mathrm{HBV}$ infection. A wild type/ $\Delta 32$ genotype was found in $18.1 \%$ participants, $1.3 \%$ were $\Delta 32 / \Delta 32$ homozygotes. The frequency of allele A of CCR2 gene was $11.1 \%$. Age was found to be a correlate to the anti-HBs titre. When adjusted to age, the difference in anti-HBs titres between $\Delta 32 / \Delta 32$ homozygotes and other CCR5 genotypes was statistically significant. No statistically significant association between anti-HBs titres and CCR2 genotypes was found.

\subsection{Anti-HBs Titres}

In patients who completed a 3-dose HBV vaccination schedule, anti-HBs titres were negatively correlated with age. Decreasing responses to immunization with advanced age have been described previously [5,23]. A model on sero-protection rates presented by Van Der Meeren et al. showed a statistically significant decrease in anti-HBs sero-protection rate with age, and predicted that it remains $\geq 80 \%$ up to 60 years of age [23]. This is in line with our results: $83 \%$ of patients from PCCs, with the mean age of 60 years, gained sero-protection after HBV vaccination. Although some other studies reported correlations between anti-HBs levels after HBV vaccination and host factors, such as male gender, obesity, and smoking [3,5,23], similarly to Williams et al. [24] we did not find such correlations, possibly due to the limited sample size.

\subsection{Frequencies of $\triangle 32$ CCR5 and $190 G>A$ CCR2 Allele}

According to medical literature, the mean frequency of $\triangle 32$ CCR5 allele in Europe is approximately $10 \%$, with the highest allele frequency (12\%) observed among Nordic populations and the lowest ( $5 \%)$ in the regions of Southeast Mediterranean [10]. In Poland $\triangle 32$ CCR5 allele frequency is comparable to that found in Caucasian populations and follows the pattern of the north-southern gradient observed in Europe. The lowest frequencies of $\triangle 32$ CCR 5 were detected in provinces in central and north-western regions of the country [11]. The frequency of the $\Delta 32$ allele among PCCs patients followed the pattern of the north-southern gradient observed in Europe [10] and was similar to that reported in orthopaedic trauma patients and staff [25], as well as newborns [26] from regional hospitals and data reported among Polish blood donors [11]. Moreover, there were no differences in the frequencies of both studied polymorphisms between the study group and HAPMAP controls [20].

\subsection{The Association between Anti-HBs Titres and CCR5 and CCR2 Genotypes}

Chemokines are responsible for innate and adaptive immune responses and surveillance [27]. The variation in chemokine release is individual and linked to polymorphisms of genes. Only a small number of studies_-involving animals and humans-have been carried out regarding the involvement of chemokines in response to infectious agents [28-32]. As an example, Algood et al. tested the consequences of $\Delta 32 / \Delta 32$ genotype in mice and found a more robust T-cell response to several infectious agents [31]. The authors observed more dendritic cells in lymph nodes and increased pulmonary inflammation, due to a greater T-cell response in Mycobacterium tuberculosis infection in mutant $(\Delta 32 / \Delta 32)$ mice, when compared to wt/wt mice.

Given the importance of cell response in HBV infection, including a finding that the production of a non-functional CCR5 $(\triangle 32 C C R 5)$ increases the likelihood of recovery from HB in humans $[11,12,33]$, and given the increased T-cell response to various antigens observed in animal models [31], we conducted the first study on the human population and hypothesized that both homozygous $\triangle 32 / \triangle 32$ of CCR5 gene and homozygous AA of CCR2 gene might be bio-markers for immunological response in subjects after a HBV vaccination. This hypothesis was tested by genotyping CCR2 and CCR5 genes for two SNPs (190G > A CCR2 and $\triangle 32$ CCR5) in a group of Polish patients in the context of response to $\mathrm{HBV}$ vaccination. 
Age was found to be a negative correlate to the anti-HBs titre. The median anti-HBs titre in $\Delta 32 / \Delta 32$ homozygotes was more than ten times lower than observed in patients with other genotypes, this was a statistically significant difference. Though, it might be hypothesized that CCR5 mutation can influence the outcome of HBV immunization, i.e., be associated with impaired response to vaccination with the passage of time.

However, vaccine response is a complex issue with multiple factors involved, including genetic variations. Furthermore, genetic interactions are also complex, therefore it is unlikely that a single allelic variants investigation would be enough to show their dominant role in impaired immunologic response after $\mathrm{HBV}$ vaccination. If a singular SNP was considered as an independent risk factor toward impaired vaccine response, it may an extended period to observe. This might explain why the impact of a bi-allelic polymorphism is best observed in older age. Over the years, most environmental factors (e.g., obesity, smoking status) begin to be set at a more constant level, the direct impact of a genetic variation on the selected clinical parameter can be seen more clearly.

This preliminary evidence needs further study on the role genetic factors play in the immune response to the vaccine, including a decrease in vaccine immunogenicity. Thorough medical literature search was unsuccessful in finding previous studies related to this subject, therefore comparisons with other surveys are not presented in this paper. Any consideration on the clinical utility of our findings should include a question of CCR5 polymorphism as one of the possible targets for the screening of $\mathrm{HBV}$ vaccination effectiveness.

\section{Limitations}

A clear advantage of the current study is its pioneering character-to our knowledge this is the first study on the human population which examined $\triangle 32$ CCR5 and 190G > A CCR2 polymorphisms in the context of a response to HBV vaccination. Moreover, the study was conducted among patients from randomly selected PCCs, therefore the study population may be representative of the whole region. In addition, the frequencies of both studied polymorphisms are comparable to those found in Caucasian populations $[7,8,16]$.

The main limitations of this study were the small sample size of subjects (including the number of individuals in the group with $\Delta 32 / \Delta 32$ ), recruited from the one region, and involving one ethnic group. However, due to the low prevalence of $\Delta 32 / \Delta 32 C C R 5$ homozygotes in the Caucasian population (less than 1\% [11]), collecting samples from homozygotes vaccinated for HBV with 3 doses, who have not been infected with HBV previously, was difficult. These limitations made our sample ever smaller. Therefore, data are presented as a preliminary report, and the conclusions that can be drawn are limited from such low numbers.

Due to these limitations, which may affect the results, we recommend further studies in patients presenting one month after taking the third HBV vaccination dose, with a larger sample size and different ethnicities, to validate our results. Also, due to the interference of other cytokines in immunologic response after HBV vaccination, the effect of other allelic variants should also be investigated. Therefore, we recommend further studies related to this issue.

\section{Conclusions}

Our study-which is a preliminary report that suggest the topic deserves further observation-underscores the possible involvement of CCR5 polymorphism in impairing the immunologic response to HBV vaccination, predominantly in relation to the passage of time. Additional studies are necessary to validate our findings, as well as to clarify the clinical utility of CCR5 polymorphism. This paper may contribute to further anthropological and epidemiological surveys on the subject. 
Acknowledgments: This study was supported by the Pomeranian Medical University grant FSN-303/05/13.

Author Contributions: Maria Ganczak was the principal investigator involved in conceptualization of the project and study design, defining exclusion and inclusion criteria of study subjects, collecting blood samples, also compiled the data, wrote the manuscript; Karolina Skonieczna-Żydecka was involved in oversee complete genetic analyses in the laboratory, in molecular genetic analyses and statistical analyses; Grażyna Adler was the principal geneticist involved in study design, oversee complete genetic analyses in the laboratory; Marzena Drozd-Dabrowska was responsible for identification of study subjects from their respective primary care clinics and for collecting blood samples, together with Maria Gańczak compiled the data and reviewed the final version of manuscript; Grażyna Adler, Karolina Skonieczna-Żydecka drafted and reviewed the final version of manuscript.

Conflicts of Interest: The authors declare no conflict of interest.

\section{References}

1. Lozano, R.; Naghavi, M.; Foreman, K.; Lim, S.; Shibuya, K.; Aboyans, V.; Abraham, J.; Adair, T.; Aggarwal, R.; Ahn, S.Y.; et al. Global and regional mortality from 235 causes of death for 20 age groups in 1990 and 2010: A systematic analysis for the global burden of disease study 2010. Lancet 2012, 380, 2095-2128. [CrossRef]

2. Ślusarczyk, J. Vaccines and vaccination preventing viral hepatitis-Successes and misery. Zakażenia 2008, 6, 3-6.

3. Van Damme, P.; Van Herck, K. A review of the long-term protection after hepatitis A and B vaccination. Travel. Med. Infect. Dis. 2007, 5, 79-84. [CrossRef] [PubMed]

4. Shepard, C.W.; Simard, E.P.; Finelli, L.; Fiore, A.E.; Bell, B.P. Hepatitis B virus infection: Epidemiology and vaccination. Epidemiol. Rev. 2006, 28, 112-125. [CrossRef] [PubMed]

5. Van der Wielen, M.; Van Damme, P.; Chlibek, R.; Smetana, J.; von Sonnenburg, F. Hepatitis A/B vaccination of adults over 40 years old: Comparison of three vaccine regimens and effect of influencing factors. Vaccine 2006, 24, 5509-5515. [CrossRef] [PubMed]

6. Wong, M.M.; Fish, E.N. Chemokines: Attractive mediators of the immune response. Semin. Immunol. 2003, 15, 5-14. [CrossRef]

7. Wu, L.; LaRosa, G.; Kassam, N.; Gordon, C.J.; Heath, H.; Ruffing, N.; Chen, H.; Humblias, J.; Samson, M.; Parmentier, M.; et al. Interaction of chemokine receptor CCR5 with its ligands: Multiple domains for HIV-1 gp120 binding and a single domain for chemokine binding. J. Exp. Med. 1997, 186, 1373-1381. [CrossRef] [PubMed]

8. Kurihara, T.; Warr, G.; Loy, J.; Bravo, R. Defects in macrophage recruitment and host defense in mice lacking the CCR2 chemokine receptor. J. Exp. Med. 1997, 186, 1757-1762. [CrossRef] [PubMed]

9. Dean, M.; Carrington, M.; Winkler, C.; Huttley, G.A.; Smith, M.W.; Allikmets, R.; Goedert, J.J.; Buchbinder, S.P.; Vittinghoff, E.; Gomperts, E.; et al. Genetic restriction of HIV-1 infection and progression to AIDS by a deletion allele of the CKR5 structural gene. Science 1996, 273, 1856-1862. [CrossRef] [PubMed]

10. Adler, G.; Valjevac, A.; Skonieczna-Żydecka, K.; Mackic-Djurovic, M.; Parczewski, M.; Urbańska, A.; Salkic, N.N. Frequency of CCR5 $\Delta 32$ allele in healthy Bosniak population. Bosn. J. Basic Med. Sci. 2014, 14, 150-154. [CrossRef] [PubMed]

11. Jagodzinski, P.P.; Lecybył, R.; Ignacak, M.; Juszczyk, J.; Trzeciak, W.H. Distribution of 32 alelle of the CCR5 gene in the population of Poland. J. Hum. Genet. 2000, 45, 271-274. [CrossRef] [PubMed]

12. Guergnon, J.; Combadière, C. Role of chemokines polymorphisms in diseases. Immunol. Lett. 2012, 145, 15-22. [CrossRef] [PubMed]

13. Rebbani, K.; Ezzikouri, S.; Marchio, A.; Ababou, M.; Kitab, B.; Dejean, A.; Kandil, M. Common polymorphic effectors of immunity against hepatitis $\mathrm{B}$ and $\mathrm{C}$ modulate susceptibility to infection and spontaneous clearance in a Moroccan population. Infect. Genet. Evol. 2014, 26, 1-7. [CrossRef] [PubMed]

14. Ahn, S.H.; Kim, D.Y.; Chang, H.Y.; Hong, S.P.; Shin, J.S.; Kim, Y.S.; Kim, H.; Kim, J.K.; Paik, Y.H.; Lee, K.S.; et al. Association of genetic variations in CCR5 and its ligand, RANTES with clearance of hepatitis B virus in Korea. J. Med. Virol. 2006, 78, 1564-1571. [CrossRef] [PubMed]

15. Thio, C.L.; Astemborski, J.; Bashirova, A.; Mosbruger, T.; Greer, S.; Witt, M.D.; Goedert, J.J.; Hilgartner, M.; Majeske, A.; O'Brien, S.J.; et al. Genetic protection against hepatitis B virus conferred by CCR5 Delta32: Evidence that CCR5 contributes to viral persistence. J. Virol. 2007, 81, 441-445. [CrossRef] [PubMed] 
16. Santos, E.U.; Lima, G.D.; de Oliveira, M.L.; Heráclio Sde, A.; Silva, H.D.; Crovella, S.; Maia Mde, M.; Souza, P.R. CCR2 and CCR5 genes polymorphisms in women with cervical lesions from Pernambuco, northeast region of Brazil: A case-control study. Mem. Inst. Oswaldo Cruz (Rio de Janeiro) 2016, 111, 174-180. [CrossRef] [PubMed]

17. Cheong, J.Y.; Cho, S.W.; Choi, J.Y.; Lee, J.A.; Kim, M.H.; Lee, J.E.; Hahm, K.B.; Kim, J.H. RANTES, MCP-1, CCR2, CCR5, CXCR1 and CXCR4 gene polymorphisms are not associated with the outcome of hepatitis B virus infection: Results from a large scale single ethnic population. J. Korean Med. Sci. 2007, 22, 529-535. [CrossRef]

18. Prasad, P.; Tiwari, A.K.; Kumar, K.M.; Ammini, A.C.; Gupta, A.; Gupta, R. Association of TGF beta1, TNF alpha, CCR2 and CCR5 gene polymorphisms in type-2 diabetes and renal insufficiency among Asian Indians. BMC Med. Genet. 2007, 8, 20. [CrossRef] [PubMed]

19. Rector, A.; Vermeire, S.; Thoelen, I.; Keyaerts, E.; Struyf, F.; Vlietinck, R.; Rutgeerts, P.; Van Ranst, M. Analysis of the CC chemokine receptor 5 (CCR5) delta-32 polymorphism in inflammatory bowel disease. Hum. Genet. 2001, 108, 190-193. [CrossRef] [PubMed]

20. Thorisson, G.A.; Smith, A.V.; Krishnan, L.; Stein, L.D. The international HapMap project web site. Genome Res. 2005, 15, 1592-1593. [CrossRef] [PubMed]

21. Faul, F.; Erdfelder, E.; Lang, A.G.; Buchner, A. G* Power 3: A flexible statistical power analysis program for the social, behavioral, and biomedical sciences. Behav. Res. Methods 2007, 39, 175-191. [CrossRef] [PubMed]

22. Cohen, J. Statistical Power Analysis for the Behavioral Sciences, 2nd ed.; Lawrence Earlbaum Associates: Hillsdale, NJ, USA, 1988.

23. Van Der Meeren, O.; Crasta, P.; Cheuvart, B.; De Ridder, M. Characterization of an age-response relationship to GSK's recombinant hepatitis B vaccine in healthy adults: An integrated analysis. Hum. Vaccines Immunother. 2015, 11, 1726-1729. [CrossRef] [PubMed]

24. Williams, R.E.; Sena, A.C.; Moorman, A.C.; Moore, Z.S.; Sharapov, U.M.; Drobenuic, J.; Hu, D.J.; Wood, H.W.; Xing, J.; Spradling, P.R. Hepatitis B vaccination of susceptible elderly residents of long term care facilities during a hepatitis B outbreak. Vaccine 2012, 30, 3147-3150. [CrossRef] [PubMed]

25. Ganczak, M.; Bohatyrewicz, A.; Szych, Z.; Białecki, P. Markers of hepatitis B, C and HIV in trauma orthopedics patients and staff from a Polish teaching hospital. Chir. Narz. Ruchu Ortop. Pol. 2008, 73, 83-88.

26. Parczewski, M.; Leszczyszyn-Pynka, M.; Kaczmarczyk, M.; Adler, G.; Binczak-Kuleta, A.; Loniewska, B. Sequence variants of chemokine receptor genes and susceptibility to HIV-1 infection. J. Appl. Genet. 2009, 50, 159-166. [CrossRef] [PubMed]

27. Heidari, Z.; Moudi, B.; Mahmoudzadeh-Sagheb, H.; Hashemi, M. The correlation between interferon Lambda 3 gene polymorphisms and susceptibility to hepatitis B virus infection. Hepat. Mon. 2016, 16. [CrossRef]

28. Nansen, A.; Christensen, J.P.; Andreasen, S.O.; Bartholdy, C.; Christensen, J.E.; Thomsen, A.R. The role of CC chemokine receptor 5 in antiviral immunity. Blood 2002, 99, 1237-1245. [CrossRef] [PubMed]

29. Ng-Cashin, J.; Kuhns, J.J.; Burkett, S.E.; Powderly, J.D.; Craven, R.R.; van Deventer, H.W.; Kirby, S.L.; Serody, J.S. Host absence of CCR5 potentiates dendritic cell vaccination. J. Immunol. 2003, 170, 4201-4208. [CrossRef] [PubMed]

30. Smith, M.W.; Dean, M.; Carrington, M.; Winkler, C.; Huttley, G.A.; Lomb, D.A.; Goedert, J.J.; O’Brien, T.R.; Jacobson, L.P.; Kaslow, R.; et al. Contrasting genetic influence of CCR2 and CCR5 variants on HIV-1 infection and disease progression. Science 1997, 277, 959-996. [CrossRef] [PubMed]

31. Algood, H.M.; Flynn, J.L. CCR5-deficient mice control Mycobacterium tuberculosis infection despite increased pulmonary lymphocytic infiltration. J. Immunol. 2004, 173, 3287-3296. [CrossRef] [PubMed]

32. Zhou, Y.T.; Kurihara, T.; Ryseck, R.P.; Yang, Y.; Ryan, C.; Loy, J.; Warr, G.; Bravo, R. Impaired macrophage function and enhanced T-cell-dependent immune response in mice lacking CCR5, the mouse homologue of the major HIV-1 co-receptor. J. Immunol. 1998, 160, 4018-4025. [PubMed]

33. Chang, H.Y.; Ahn, S.H.; Kim, D.Y.; Shin, J.S.; Kim, Y.S.; Hong, S.P.; Chung, H.J.; Kim, S.O.; Yoo, W.D.; Han, K.H. Association between CCR5 promoter polymorphisms and hepatitis B virus infection. Korean J. Hepatol. 2005, 11, 116-124. [CrossRef]

(C) 2017 by the authors; licensee MDPI, Basel, Switzerland. This article is an open access article distributed under the terms and conditions of the Creative Commons Attribution (CC BY) license (http:/ / creativecommons.org/licenses/by/4.0/). 